\title{
Determinants of Banking Stability: Evidence from Haiti's Banking System
}

\author{
Rocheny Sifrain \\ Independent Researcher, Port-au-Prince, Haiti \\ Email: rsifrain@gmail.com
}

How to cite this paper: Sifrain, R. (2021). Determinants of Banking Stability: Evidence from Haiti's Banking System. Journal of Financial Risk Management, 10, 80-99. https://doi.org/10.4236/jfrm.2021.101005

Received: February 9, 2021

Accepted: March 23, 2021

Published: March 26, 2021

Copyright () 2021 by author(s) and Scientific Research Publishing Inc. This work is licensed under the Creative Commons Attribution International License (CC BY 4.0).

http://creativecommons.org/licenses/by/4.0/

\begin{abstract}
This paper investigates the factors of the banking stability in Haiti, over the period of 1996 to 2017, using macroeconomic, government and institutions, banking system, and economic freedom factors measured respectively by GDP growth and exchange rate, political stability index and regulatory quality index, bank lending-deposit interest rate spread, property rights index and investment freedom index. To carry out the analysis, the yearly data have been transformed into quarterly data, giving a sample of 88 observations. By means of OLS regressions, six statistical models have been specified. Banking stability which is the response variable is measured by the $\mathrm{z}$-score. The results suggest that macroeconomic and economic freedom factors have positive effects on the banking stability, while the banking system factor impacts negatively the banking stability in Haiti. Conversely, government and institutions factor has no significant impact on the Haitian banking stability. When it comes to assess the impact of each explanatory variable (GDP growth, exchange rate, political stability index, regulatory quality index, bank lendingdeposit interest rate spread, property rights index and investment freedom index) on banking stability, the results show that they all have significant effects on the Haitian banking stability. However, when all of the independent variables are analyzed in one multiple regression together, the political stability index is not statistically significant. The findings of this study have important implications for decision makers. Governments and the Central Bank should intensity their efforts in creating a promising macroeconomic environment, adopting effective monetary policy, reducing restrictions in investment and reinforcing laws to protect property rights, in order to maintain or improve banking stability in Haiti.
\end{abstract}

\section{Keywords}

Banking Stability, Z-Score, Ordinary Least Square (OLS), Banking System, Haiti 


\section{Introduction}

The banking sector plays a vital role in the functioning of the economy of a country through intermediation. The banking sector stands between savers and borrowers, by taking funds from savers by means of deposits to lend them to those who wish to borrow, be they individuals, households, businesses or governments. In addition to these two traditional banking services, there are other forms of intermediation. For instance, investment banks connect the investors with the bond issuers. Banks are then deemed to be the lifeblood of the economic activity. If they fail to perform their functions, the effects for the whole economy could rapidly become so wide-reaching that even the banking system would be susceptible to huge shocks. Consequently, it is critical that banks can cover losses and fulfil their payment obligations. To ensure their well-functioning, banks must comply with strict regulatory requirements. In fact, the banking sector is highly protected, regulated and supervised (Barth et al., 2006). First of all, regulation and supervision aim to maintain the safety and trustworthiness of the financial system. The second purpose is to ensure that financial services companies meet their primary fiduciary tasks. Both of duties fall under a government's judiciary to enforce contracts and protect its citizens against fraud by requiring financial institutions to publish their financial statements verified by an independent audit, in order to help depositors, borrowers, and other financial actors to make informed decisions.

It is convenient to mention that there is a large acceptance that, prior to the global financial crisis of 2007-2008, insufficient regulation and supervision of the entire financial system were a very severe shortcoming of public financial policy. The global financial crisis has greatly emphasized the importance of banks' insolvency and liquidity risk, and the methods through which risk is measured (Li, Tripe \& Malone, 2017). One of the major stages to addressing the shortcoming of the public policy was the adoption of a set of reforms known as Basel III, published by the Basel Committee on Banking Supervision (BCBS) in December 2010. One of the main reasons why the financial crisis became so devastating was that the banking sector of many countries had built up excessive on and off balance sheet leverage. This was convoyed by the wearing down of quantity and quality of capital. As a consequence, the banking system was not able to cover the resulting losses (Achterberg \& Heintz, 2012). Basel III aims to strengthen capital and liquidity regulations, given the interaction between liquidity and solvency. In other words, the purpose of Basel III rules was to contribute to the financial stability, which is defined in terms of its ability to facilitate and enhance economic processes, manage risks, absorb shocks. In addition, financial stability is considered a continuum: changeable over time and consistent with multiple combinations of the constituent elements of finance (Houben et al., 2004).

Based on the recent evolutions of the Haitian banking system, mainly the uncertain and volatile macroeconomic and sociopolitical environment in which it evolves, we aim to investigate the main determinants of its financial stability. In 
effect, the Haitian banking industry is comprised of eight banks (seven national banks and one foreign bank branch). These are two types: seven commercial banks and one savings and housing bank. Besides the foreign bank branch, there are five private banks and two state-owned banks. The banking system is regulated by the Central Bank of Haiti, Banque de la République d'Haïti (BRH). In 2020, the total assets of the whole Haitian banking sector are estimated at USD 5.69 billion against USD 4.31 billion in 2019, i.e. a yearly growth of $32.0 \%$ (BRH, 2020). This performance is influenced by the appreciation of the local currency, the Haitian Gourde (HTG), passing from 1USD/93.3162 September 20219 to 1USD/65.9193 HTG in September 2020, a decrease of $29.4 \%$ over the period. In addition to the impacts of the Covid-19 crisis in 2020, Haiti was locked down twice in 2019, due to social and political protests, which negatively impacted the economic environment and affected unfavorably the profitability level of the Haitian banking system. Both Returns on Assets (ROA) and Returns on equity (ROE) deteriorated, passing respectively from $1.87 \%$ and $21.70 \%$ in 2019 to $1.15 \%$ and $12.98 \%$ in 2020 (BRH, 2020). Therefore, the Haitian banking stability might be affected. Hence, the following research questions:

1) What are the key factors that contribute to the banking system stability in Haiti?

2) Is there any relationship between external factors (Macroeconomic, Governance and Institutions, Economic Freedom) and banking system stability?

3) How is banking stability influenced by banking system factors?

The remainder of this paper is organized as follows: Section 2 explores briefly the concept of Z-score, the measure of banking stability used in our empirical analysis; Section 3 covers the literature review related to the researched topic; Section 4 describes the data and the methodology used to carry out our analysis; Section 5 highlights and discusses the main findings of the research; and Section 6 concludes the paper.

\section{Z-Score as a Measure of Banking Stability}

The $\mathrm{Z}$-score is the most commonly used in the empirical banking literature to estimate a bank's probability of insolvency. This is one of the indicators used by the World Bank in the Global Finance Development Database to measure financial stability. Bank Z-scores capture the probability of default of a country's baking system. The z-score compares the buffer of a country's banking system, i.e. capitalization and returns, with the volatility of those returns. It is defined as: Zscore $=\frac{(\mathrm{ROA}+\mathrm{EA})}{\sigma(\mathrm{ROA})}$, where $\mathrm{ROA}$ is the rate of return on assets, EA is the ratio of equity to assets, and $\sigma(\mathrm{ROA})$ is an estimate of the standard deviation of the rate of return on assets. The basic principle of the Z-score measure indicates how much variability in returns can be absorbed by capital. Without the banking system becoming insolvent (Li, Tripe, \& Malone, 2017). A higher $\mathrm{Z}$-score indicates a lower probability of insolvency. 
The Z-score that has become very popular nowadays as an indicator of bank risk-taking among academics was initially built on work by Roy (1952) and successively developed by Boyd and Graham (1986), Hannan \& Hanweck (1988), and Boyd, Graham \& Hewitt (1993). The popularity of the Z-score in measuring banking stability is particularly related to the fact that it is very simple to be computed, using openly available accounting data only. However, the fact that the Z-scores are merely based on accounting data might be viewed as one of their limitations, because they are only as good as the underlying accounting and auditing framework. According to the World Bank, an advantage of the Z-scores is that they allow the comparison of the risk of default in different groups of institutions, which may differ in their ownership of objectives, but face the risk of solvency.

\section{Review of Related Literature}

The determinants of banking stability and its impacts on the whole financial system stability might differ across countries. As a result, policymakers, national bank regulators and academics might be interested in understanding banking stability determinants in a specific country. In the empirical literature, numerous studies focused on factors that drive banking stability. The most commonly used factors are: economic factors, regulation, financial structure and institutional factors.

\subsection{Economic Factors}

Shayegani \& Arani (2012) show that the financial stability of the banking system can be affected by macro-economic variables. Using Z-score as a bank risk measure and pooled ordinary least squares estimation method, their paper indicates that the growth of the real Gross Domestic Product (GDP) increases the stability of the private banks, state-owned banks and the stability of the whole banking system of Iran. Investigating the main drivers of banking stability in the Romanian banking sector with z-score as a measure of financial stability, Diaconu \& Oanea (2015) find that the GDP growth is a significant factor which positively influences the financial stability of cooperative banks, while it has no impact on the financial stability of commercial banks. Their paper also shows that the inflation rate has no significant impact either on cooperative banks or on commercial banks in Romania. Using Z-score to calculate the financial stability, through lag Autoregressive distributive lag (ARDL) mode and Impulse Response Function (IRF), Karim, Al-Habshib \& Abduh (2015) show long run relationship between the stability of the whole banking system in Indonesia and macroeconomic factors (GDP, Interest rates and Consumer Price Index (CPI) in percentage).

\subsection{Regulation and Supervision}

Providing new data and measures of bank regulatory and supervisory policies in 
180 countries from 1999 to 2011, Barth et al. (2013) indicate that banking instability may be linked to incomplete regulation or ineffective supervision, although both incomplete regulation and ineffective supervision are correlated and cannot be analyzed separately. Indeed, incomplete regulation is defined as a weak regulatory framework which implies the requirement for regulatory reforms (Financial Crisis Inquiry Commission, 2011), while ineffective supervision refers to using weak supervisory tools, and the necessity to adopt the most effective supervisory tools and styles (Barth et al., 2013). Empirically, the impact of strict supervision on banking stability is relatively inconclusive (Ozili, 2018). Researchers like Delis \& Staikouras (2011) and Bhattacharya et al. (2002) argue that strict banking supervision can reduce banks' risk-taking and enhance then timing of supervisory intervention during periods of instability. Conversely, Barth et al. (2006, 2008) point out that strict banking supervision does not involve improvements in banking stability.

\subsection{Bank Risk}

Empirical evidence shows that bank risk can influence banking stability. Using both Z-score and stability inefficiency as measures of stability, Tan \& Anchor (2016) investigate the inter-relationships between profitability and stability in the Chinese banking industry, through a sample of commercial banks from 2003 to 2013, under an auto-regressive-distributed linear model. Employing Different types of Generalized Method of Moments (GMM) estimators, their paper shows that higher insolvency risk (lower bank stability) involves higher profitability of Chinese commercial banks and as well that higher profitability gives rise to higher bank fragility. Tan \& Floros (2013) examine the relationship between bank efficiency, risk and capital, using 101 Chinese banks from 2003 to 2009, under a three stage least square method in a panel data framework. They show a positive and significant relationship between risk and efficiency in Chinese banking sector, while the relationship between risk (measured by Z-score) and level of capitalization is negatively significant.

\subsection{Institutional Factors}

The quality of the institutions can have implications on banking stability. For instance, Mutarindwa, Schäfer \& Stephan (2018) examine how African countries' legal system and institution have implications on the governance and stability of their banks. Employing Z-score as a measure of bank resilience (or risk-taking), they show that institutional factors, mainly the legal family of origin, political stability, contract enforcement and strength of investor protection support central corporate governance reforms. In addition, under a difference-in-difference approach, the authors indicate the impact of institutions on banks. With the establishment of a corporate, governance reform in countries, banks display better internal governance and higher stability. Similarly, Arias, Maquieira \& Jara (2019) investigate how the legal and institutional environment 
have implications on banking system performance (measured by the Z-score), with data on 52 countries' banking system over the period of 2005-2014. Under Panel data and controlling for financial and economic development indicators, their paper show several relationships associated with banking system performance. For instance, banking system performance is positively affected by a higher level of legal protection for both lenders and borrowers. Likewise, a positive relationship between the degree of law enforcement and banking system performance is observed. Conversely, neither the degree of information sharing nor the control of corruption has a significant effect on banking system performance.

\subsection{Financial Structure}

The stability of the banking sector can be affected by banking concentration. There are two contrasting views on the relationship between banking concentration and banking stability (Ozili, 2018). Allen \& Gale (2004) argue that banks in more concentrated markets will minimize risky lending, because of lower competition in the markets. According to Sáez \& Shi (2004), when the failure of a bank threatens the stability of the banking system, banks in more concentrated markets can certainly reach an agreement to rescue the troubled bank to prevent prevalent bank failure arising from contagion. As a result, contagion is less likely to take place in more concentrated markets. In addition, monitoring a system with only a few large banks is much less complicated than one with many small banks (Ozili, 2018).

On the contrary, Boyd and De Nicoló (2005) claim that banks in more concentrated markets can charge higher loan interest rates which can increase the moral hazard problem as to borrowers inducing them to invest in riskier projects, which may weaken the banking system stability when losses are realized. As well, Mishkin (1999) argues that banks in concentrated markets can become too-big-to fail, which leads to a moral problem from bank managers. According to Beck et al. (2006), the supervision of concentrated banking markets may be problematic if banks in such markets are susceptible to be larger and more complex than their counterparts operating in less concentrated markets.

Ali, Intissar \& Zeitun (2018) investigate the relationship between banking concentration and financial stability, using a sample of 156 developed and developing countries over the period 1980-2011. Analyzing the direct effect of banking concentration on the financial stability, their paper suggests that the financial stability is not directly affected by concentration. When considering profitability and interest margin as two indirect channels, the results indicate that concentration has a positive and stabilizing impact on financial stability through the profitability channel, and a negative and destabilizing impact by means of the interest rate channel. Furthermore, their study shows that concentration has a direct and indirect effect on financial stability during crisis periods, but no direct effect on financial stability during normal periods. 
Using Z-score as measure of financial stability and aggregate balance sheet from banks across the 25 Member States of the European Union during the period of 1997 to 2005, under a country-specific random-effects model, Uhde and Heimeshoff (2009) show that national banking market concentration is negatively associated with banking stability in the European Union. The authors also observe that Eastern European banking markets presenting a lower level of competitive pressure, fewer diversification opportunities and higher fraction of government owned banks are more susceptible to financial fragility whereas capital regulations have positive implications on financial stability overall European Union.

Overall, there is important empirical evidence for banking stability determinants in European, Asian, African countries. However, to the best of our knowledge, there is no study that looks at the determinants of the banking stability in Haiti; or empirical evidence for banking stability drivers in Haiti would be very limited in the banking literature. Our contribution to the literature is therefore to examine the determinants of the banking stability in Haiti, in order to identify factors that have implications on it.

\section{Data and Methodology}

\subsection{Data}

The data used in this research are from TheGlobalEconomy.com, which is a site providing business and economic data for 200 countries

(https://www.theglobaleconomy.com/). We collected yearly data for Haiti over the period of 1996 to 2017, which resulted in 22 observations for each variable. Since the sample is not large (less than 30 observations), due to the unavailability of data for some variables before 1996 and after 2017, we run the normality test using Shapiro-Wilk's method in R Software. Most of the variables are not normally distributed. To address this problem, we converted the yearly data into quarterly data, using Denton-Cholette method in R Software. We then obtained 88 observations for each variable during the period under study.

This paper investigates the impacts of four types of factors on the Haitian banking system stability. These are: 1) the Macroeconomic category which is measured by the Gross Domestic Product Growth and the Exchange rate; 2) the Governance and institutions variables evaluated by the Political Stability Index and The Regulation Quality Index; 3) the Banking system variable represented by Bank lending-deposit interest rate spread; and 4) the Economic freedom assessed by the Investment freedom index and the Property rights index. These four types of variables are described in Table 1.

\subsection{Research Method}

Like Kozarić \& Dželihodžić (2020) and Alshubiri (2017), we used the Ordinary Least Squares (OLS) regression to estimates the determinants of the financial stability of the Haitian banking system. OLS is a method for estimating the 
Table 1. Description of variables used in this research.

\begin{tabular}{clcc}
\hline Variable & \multicolumn{1}{c}{ Description } & Measures and definition & Expected effect \\
\hline \multicolumn{1}{c}{ Dependent variable } \\
\hline Banking stability (BS) & $\begin{array}{l}\text { It refers to the ability of a banking system } \\
\text { to facilitate and enhance economic } \\
\text { processes, manage risks, absorb shocks }\end{array}$ Zscore $=\frac{(\mathrm{ROA}+\mathrm{EA})}{\sigma(\mathrm{ROA})}$ \\
\hline \multicolumn{1}{c}{ Independent variables }
\end{tabular}

\section{Independent variables}

Macroeconomic (ME)

Governance and Institutions (GI)
It refers to economic indicators at the country level and the extent of their impact on the economic cycle and financial systems, determined by the flexibility of policies and procedures in the country and the control of fiscal and monetary policy, which is reflected on the financial stability of the banking system.

This variable measures the performance of governments, using indicators of governance and institutional quality. It implies the ability of governments to create high-quality institutional environment that can facilitate the financial stability of the banking system.

It refers to internal indicators of the

Banking system (BS) banking sector that contribute to its efficiency, which in turn will be reflected on its financial stability.
Gross Domestic Product Growth (GDP): Annual percentage growth rate of GDP at market prices based on constant local currency. Aggregates are based on constant 2010 U.S. dollars.

GDP: Positive ER: ? Exchange rate (ER): Local currency units per U.S. dollar.

Political stability index (PS): Perceptions of the likelihood that the government will be destabilized or overthrown by unconstitutional or violent means, including politically-motivated violence and terrorism.

The index is a composite measure as it is based on several other indexes from multiple sources including the Economist Intelligence Unit, the World Economic Forum, and the Political Risk Services, among others. The underlying indexes reflect the likelihood of a disorderly transfer of government power, armed conflict, violent demonstrations, social unrest, international tensions, terrorism, as well as ethnic, religious or regional conflicts

Regulatory quality index (RQ): Perceptions of the ability of the government to formulate and implement sound policies and regulations that permit and promote private sector development.

Many variables are used in the contruction of this index, such as price controls, discriminatory tariffs, extent of market dominance, regulatory burden, tax inconsistency, trade policy, business regulatory environment, market organization, etc. There are from different data sources (World Economic Forum Global Competitiveness Report, Global Integrity Index, Varieties of Democracy Project, World Bank Country Policy and Institutional Assessments, etc.).

Bank lending-deposit interest rate spread (BLIS): Difference between the lending rate and the deposit rate. The lending rate is the rate charged by banks on loans to the private sector and the BLIS: Negative deposit interest rate is the rate offered by commercial banks on three-month deposits.
PS: Positive

RQ: ? 


\section{Continued}

Economic Freedom
This variable refers to the ability to prosper through the free exercise of economic activity while letting others do the same. The principles of economic freedom generate long-lasting economic growth, opportunity and prosperity that should contribute to enhance the financial stability of the banking system.
Investment freedom index (IF): A variety of investment restrictions (burdensome bureaucracy, restrictions on land ownership, expropriation of investments without fair compensation, foreign exchange controls, capital control, security problems, a lack of basic investment infrastructure, etc.).

IF: Positive PR: Positive

Property rights index (PR): The degree to which a country's laws protect private property rights and the degree to which its government enforces those laws. and businesses to enforce contracts.

unknown parameters in a linear regression model. This statistical technique allows minimizing the sum of squared vertical distances between the observed responses in the dataset and the responses predicted by linear approximation (Daly \& Frikha, 2016).

This research formulates six (6) equations. These are specified as follows:

$$
\begin{gathered}
\mathrm{BS}_{t}=\beta_{0}+\beta_{1} \mathrm{ME}_{t}+\beta_{2} \mathrm{GI}_{t}+\beta_{3} \mathrm{BS}_{t}+\beta_{4} \mathrm{EF}_{t}+\varepsilon_{t} \\
\mathrm{BS}_{t}=\beta_{0}+\beta_{1} \mathrm{GDP}_{t}+\beta_{2} \mathrm{ER}_{t}+\varepsilon_{t} \\
\mathrm{BS}_{t}=\beta_{0}+\beta_{1} \mathrm{PS}_{t}+\beta_{2} \mathrm{RQ}_{t}+\varepsilon_{t} \\
B S_{t}=\beta_{0}+\beta_{1} B L I S_{t}+\varepsilon_{t} \\
\mathrm{BS}_{t}=\beta_{0}+\beta_{1} \mathrm{IF}_{t}+\beta_{2} \mathrm{PR}_{t}+\varepsilon_{t} \\
\mathrm{BS}_{t}=\beta_{0}+\beta_{1} \mathrm{GDP}_{t}+\beta_{2} \mathrm{ER}_{t}+\beta_{3} \mathrm{PS}_{t}+\beta_{4} \mathrm{RQ}_{t}+\beta_{5} \mathrm{BLIS}_{t}+\beta_{6} \mathrm{IF}_{t}+\beta_{7} \mathrm{PR}_{t}+\varepsilon_{t}
\end{gathered}
$$

where $t=1, \cdots, N$ denotes the time period. Our time frame is 1996-2017, initially containing yearly data and afterwards converted into quarterly for the needs of the estimation. Equation (1) estimates the effects of the Macroeconomic (ME), Governance \& Institution (GI), Banking system (BS) and Economic freedom factors on banking stability (BS). It constitutes the main model. Equation (2) estimates the effects of the macroeconomic measures (Gross Domestic Product growth/GDP and Exchange rate/ER) on banking stability (BS). Equation (3) analyzes the influences of the Governance and institution variables (Political stability/PS and Regulation quality/RQ) on banking stability. Equation (4) estimates the effects of Banking system variable (Bank lending-deposit interest rate spread/BLIS) on banking stability. Equation (5) specifies the impacts of Economic freedom factors (Investment freedom index/IF and Property rights index/PR. Equations (1) to (5) are sub model derived from Equation (1). Lastly, Equation (6) which estimates the effects of all of the seven (7) measures on banking stability. To run these regressions, we used R software.

\section{Results and Discussion}

\subsection{Descriptive Statistics and Pair-Wise Correlations}

Table 2 exhibits descriptive statistics for the dependent variable and all of explanatory variables. On average, the $\mathrm{Z}$-score is 10.1759 , with a risk of 2.4574 ; its 
Table 2. Descriptive statistics of the data.

\begin{tabular}{ccccccccc}
\hline Variables/Determinants & Abbreviation & Mean & Median & Min & Max & Std.Dev. & Skewness & Kurtosis \\
\hline Z-Score & Z & 10.1759 & 9.9870 & 6.2233 & 17.6844 & 2.4574 & 1.0598 & 1.5617 \\
Gross Domestic Product Growth & GDP & 1.6195 & 1.9679 & -4.3408 & 6.9274 & 2.2745 & -0.6296 & 0.6979 \\
Exchange rate & ER & 36.7923 & 39.8769 & 15.4880 & 65.7144 & 13.6725 & 0.1072 & -0.3384 \\
Political stability index & PS & -1.0436 & -0.9747 & -2.0819 & -0.5725 & 0.3763 & -1.0018 & 0.5259 \\
Regulatory quality index & RQ & -1.0184 & -1.0136 & -1.3937 & -0.7403 & 0.1618 & -0.5349 & -0.3058 \\
Bank lending-deposit interest & BLIS & 15.1582 & 15.2687 & 7.3620 & 34.5615 & 6.8251 & 1.0229 & 0.8016 \\
$\quad$ rate spread & & & & & & & & \\
Investment freedom index & IF & 30.9091 & 30.0002 & 5.1918 & 41.6929 & 6.1450 & -1.4802 & 6.1740 \\
Property rights index & PR & 10.1364 & 10.0000 & 9.5215 & 13.7212 & 0.6545 & 4.5348 & 20.4003 \\
\hline
\end{tabular}

Source: Author's own calculation.

maximum value is 17.6844 and 6.2233 , its minimum value. Compared to the Z-score of Dominican Republic banking system, the Z-score of the Haitian banking system is lower. For the neighbor country of Haiti, on average, the z-score is 25.2404, with a maximum value of 30.4300 over the period of 1996 to 2017. These figures indicate that the banking system of the Dominican Republic is much more stable than the Haitian banking system. The Z-score is positively skewed (1.0598) and its distribution is leptokurtic, i.e. it has heavier tails (1.5617). On average, the GDP growth rate is $1.62 \%$, with a standard deviation of $2.27 \%$. Its maximum value and minimum value over the period under consideration are respectively $6.93 \%$ and $-4.34 \%$. The exchange rate has evolved between 15.4880HTG/1USD and 65.7144 HTG/1USD, with an average of 36.7923 HTG/1USD and a standard deviation of 13.6725 HTG/USD. These values indicate the depreciation of the local currency relatively to the US dollar. The mean of the political stability index ( -2.5 weak; 2.5 strong) is -1.0436 , with a standard deviation of 0.3763 . Its minimum value and maximum value are respectively -2.0819 and -0.5725 . These figures suggest that Haiti is not a politically stable country. On average, the regulatory quality index ( -2.5 weak; 2.5 strong) is -1.0184 , with a standard deviation of 0.1618 . Its value is within the range of -1.3937 to -0.7403 , indicating that Haiti has a weak regulatory quality. The Bank lending-deposit interest rate spread is considered to be a profit margin. The greater the spread, the more profitable the banking system is likely to be. On average, its value is $15.16 \%$, with a total risk of $6.83 \%$. The maximum observed is $34.56 \%$ while the minimum spread is $7.36 \%$. The spread is positively skewed (1.02\%). Haiti experienced over the period under consideration an average of 30.9091 for its investment freedom index (0 - 100 scores), with a standard deviation of 6.1450 . with a maximum score of 41.6929 , Haiti can be considered a country where the flow of capital investment of individuals and firms is constrained. Finally, on average, the property rights index (0 - 100 scores) is 10.1364 , with a slight standard deviation of 0.6545 . The maximum value of 13.7212 indicates that the degree of Haiti's legal protection of private property 
rights is very low.

The Pearson correlation matrix presented in Table 3 shows that banking stability defined by the Z-score is positively correlated with the two macroeconomic variables (GDP growth and exchange rate). As well, the Haitian banking stability is positively correlated with the two freedom economic variables (property rights index and investment freedom index). In contrast, the Haitian banking stability is negatively correlated with the bank lending-deposit interest rate spread, while the result is migrated for the two governance and institutions variables, i.e. the Haitian banking stability is positively correlated with the political stability index and negatively associated with the regulatory quality index. On the other hand, the bank lending-deposit interest rate spread and the political stability index are strongly negatively correlated. The results show a negative relationship between the GDP growth and the exchange rate. This outcome is not in line with the traditional wisdom according to which high foreign exchange rate may be useful for export and then promote GDP growth. This can be explained by the fact that Haiti is an import-oriented economy. As such, the country is unable to really benefit from the currency depreciation to stimulate its economic growth. The political stability index and the regulatory quality index exhibit a positive relationship. The property rights index and the investment freedom index are also positively correlated.

\subsection{Estimation Results}

\subsubsection{Analysis of OLS Regression of Each Independent Variable}

Table 4 exhibits the results of OLS regression analysis of the macroeconomic factor on baking stability, measured by the GDP growth and the exchange rate. The outputs indicate that both GDP growth and exchange rate are highly statically significant at $1 \%$ level, with respective p-value of $3.91 \mathrm{e}-06$ and $<2 \mathrm{e}-16$, less than 0.05 which is generally considered a good cut-off point. The Haitian banking stability is then affected by the GDP growth and the exchange rate. For every unit increase in the GDP growth, the banking stability will go up by 0.335 . For every unit increase in the exchange rate (the depreciation of local currency),

Table 3. Pairwise correlation matrix.

\begin{tabular}{ccccccccc}
\hline Variables & Z & GDP & ER & BLIS & PS & RG & PR & IF \\
\hline Z & 1 & & & & & & & \\
GDP & 0.26 & 1 & & & & & & \\
ER & 0.76 & -0.07 & 1 & & & & & \\
BLIS & -0.68 & -0.35 & -0.26 & 1 & & & & \\
PS & 0.5 & 0.38 & 0.1 & -0.83 & 1 & & & \\
RG & -0.2 & 0.37 & -0.5 & -0.16 & 0.16 & 1 & & \\
PR & 0.63 & -0.04 & 0.43 & -0.24 & 0.21 & -0.4 & 1 & \\
IF & 0.64 & -0.17 & 0.65 & -0.47 & 0.17 & -0.45 & 0.31 & 1 \\
\hline
\end{tabular}

Source: Author's own calculation. 
Table 4. OLS regression analysis of macroeconomic factor on banking stability.

\begin{tabular}{ccccc}
\hline Macroeconomic factor & Coefficient & Std. Error & $\mathrm{t}$ value & $\operatorname{Pr}(>|\mathrm{t}|)$ \\
\hline $\begin{array}{c}\text { Intercept } \\
\text { Gross Product Domestic } \\
\text { Growth (GDP) }\end{array}$ & 4.501 & 0.462 & 9.744 & $1.69 \mathrm{e}-15^{* * *}$ \\
Exchange rate (ER) & 0.335 & 0.068 & 4.937 & $3.91 \mathrm{e}-06^{* * *}$ \\
\hline $\mathbf{R}$ & 0.140 & 0.011 & 12.378 & $<2 \mathrm{e}-16^{* * *}$ \\
\hline 0.667 & $\mathbf{R}^{2}$ & p-value & & \\
\hline
\end{tabular}

Source: Author's own calculation from R Software.

the banking stability will increase by 0.140 . The overall model is significant with a p-value $<2.2 \mathrm{e}-16$, less than 0.05 . Moreover, $66 \%$ of the variation observed in banking stability can be explained by the variables GDP growth and exchange rate.

Regarding the GDP growth, this research is consistent with Karim, Abduh \& Alhabshi (2015) and Kozarić \& Dželihodžić (2020). Improvement in macroeconomic environment, particularly in the GDP growth, contributes to reduce non-performing loans and then enhance credit quality. Accordingly, the profitability of the whole banking system will be positively affected. This result will imply the maintenance of the Haitian banking stability. On the other hand, the positive effects of the depreciation of the exchange rate on the banking stability could be attributed to the fact that the Haitian economy is partially dollarized with USD deposits representing $62.76 \%$ of the total deposits of the whole banking sector in 2016 against 59.28\% in 2015 (BRH, 2016). With the depreciation of the exchange rate HTG/USD, the deposits in foreign currency will tend to increase, impacting positively the banking sector performance. In addition, the share of the Haitian households receiving private transfers (overall in USD) is 69\% (ECVMAS, 2012). This proportion should increase, based on the massive immigration of the population to Chile and Brazil during the past three years. The depreciation of the exchange rate could then imply an improvement in the household consumption expenditure, affecting favorably the economic activity, which can affect in turn positively the profitability of banks.

Table 5 shows the results of OLS regression analysis of Governance and institutions factor, measured by the political stability index and regulatory quality index. The outputs suggest that the political stability index is statically significant at $1 \%$ level, while the regulatory quality index is statistically significant at $5 \%$ level. The political stability index has a positive effect on banking stability, because for every unit increase in the index, banking stability will go up to 3.5547. Conversely, the regulatory quality index affects negatively the banking stability. For every unit increase in the regulatory quality index, the banking stability will decrease by -4.3879 . The overall model is statically significant with a p-value of $3.83 \mathrm{E}-08$, less than 0.05 . The variation in the banking stability can be explained by the variables political stability index and the regulatory quality 
Table 5. OLS regression analysis of governance and institutions factor on banking stability.

\begin{tabular}{ccccc}
\hline $\begin{array}{c}\text { Governance and } \\
\text { Institutions factor }\end{array}$ & Coefficient & Std. Error & $\mathrm{t}$ value & $\operatorname{Pr}(>|\mathrm{t}|)$ \\
\hline Intercept & 9.4169 & 1.4446 & 6.519 & $4.81 \mathrm{e}-09^{* * *}$ \\
Political stability index (PS) & 3.5547 & 0.5865 & 6.061 & $3.59 \mathrm{e}-08^{* * *}$ \\
Regulatory quality index (RQ) & -4.3879 & 1.364 & -3.217 & $0.00183^{* *}$ \\
\hline $\mathbf{R}$ & $\mathbf{R}^{2}$ & p-value & & \\
\hline 0.3309 & 0.315 & $3.83 \mathrm{E}-08$ & & \\
\hline
\end{tabular}

Source: Author's own calculation from R Software.

index by only $32 \%$.

Concerning the political stability, this research is in line with Mutarindwa, Schäfer \& Stephan (2018). This output could be explained by the fact that political stability tends to lead to better socioeconomic conditions, create a favorable environment for investment, with positive effects on the banking sector activities. More credit can be granted and then quality of the existing loan portfolio could be improved, which could imply enhancement of the whole banking system profitability. As a consequence, the risk of crises for the banking system will be reduced. The inverse relationship observed between the regulatory quality index and the banking stability could be due to the fact that banks must comply with regulations in order to guarantee their well-functioning. However, too many reforms, regulations might constitute some barriers to the development of the banking sector. For instance, over the period under study, the Central Bank of Haiti (BRH) increased several times the coefficients of compulsory reserves for the Haitian banking system, which could negatively affect banks capacity to grant loans to individuals and businesses.

Table 6 summarizes the results of OLS regression analysis of banking system factor on banking stability, measured by Bank lending-deposit interest rate spread. The results indicate that banking stability is strongly affected by the banking lending-deposit interest rate spread. This is highly statistically significant at $1 \%$ level, with a p-value of $2.02 \mathrm{e}-13$, less than 0.05 . The lending-deposit interest rate spread can explain at $46 \%$ the variation observed in banking stability. For every unit increase in the banking lending-deposit interest rate spread, the banking stability will decrease by -0.246 .

This output is consistent with Motelle \& Biekpe (2014) and can be related to the fact that high borrowing costs may make it difficult for borrowers to repay their loans and increase the volume of non-performing. Accordingly, the deterioration of the portfolio quality may contribute to the banking instability.

The outputs of OLS regression of economic freedom factor on banking stability are presented in Table 7. Both investment freedom index and property rights index can strongly and positively affect the banking stability. These are statistically significant at $1 \%$ level, with p-value of respectively $1.24 \mathrm{e}-09$ and $3.49 \mathrm{e}-09$, 
Table 6. OLS regression analysis of Banking system factor on banking stability.

\begin{tabular}{ccccc}
\hline Banking system factor & Coefficient & Std. Error & $\mathrm{t}$ value & $\operatorname{Pr}(>|\mathrm{t}|)$ \\
\hline $\begin{array}{c}\text { Intercept } \\
\begin{array}{c}\text { Bank lending-deposit interest } \\
\text { rate spread (BLIS) }\end{array}\end{array} \mathbf{c}^{13.910}$ & 0.470 & 29.578 & $<2 \mathrm{e}-16^{* * *}$ \\
\hline $\mathbf{R}$ & -0.246 & 0.028 & -8.699 & $2.02 \mathrm{e}-13^{* * *}$ \\
\hline 0.4681 & $\mathbf{R}^{2}$ & $\mathrm{p}$-value & \\
\hline
\end{tabular}

Source: Author's own calculation from R Software.

Table 7. OLS regression analysis of economic freedom factor on banking stability.

\begin{tabular}{ccccc}
\hline Economic Freedom factor & Coefficient & Std. Error & $\mathrm{t}$ value & $\operatorname{Pr}(>|\mathrm{t}|)$ \\
\hline Intercept & -13.838 & 2.595 & -5.332 & $7.90 \mathrm{e}-07^{* * *}$ \\
Investment freedom index (IF) & 0.195 & 0.029 & 6.823 & $1.24 \mathrm{e}-09^{* * *}$ \\
Property rights index (PR) & 1.773 & 0.269 & 6.591 & $3.49 \mathrm{e}-09^{* * *}$ \\
\hline $\mathbf{R}$ & $\mathbf{R}^{2}$ & $\mathrm{p}$-value & \\
\hline 0.606 & 0.597 & $<2.2 \mathrm{e}-16$ & \\
\hline
\end{tabular}

Source: Author's own calculation from R Software.

less than 0.05 . The overall model is statistically significant with a p-value < $2.2 \mathrm{e}-16$. The variation in banking stability can be explained by investment freedom index and property rights index at $60 \%$. For every unit increase in the investment freedom index and the property rights index, the banking stability will increase respectively by 0.195 and 1.773 .

The results obtained can be explained by the fact an economy where there are less restrictions for investment and laws that can protect private property rights, businesses will tend to grow. Consequently, the profitability of banks can increase and risk-taking can be reduced, contributing to the banking stability.

\subsubsection{Analysis of OLS Regression of All Independent Variables}

Table 8 shows OLS regression analysis of macroeconomic, banking system, governance and institutions and economic freedom factors on banking stability. The four factors are treated as independent variables. As composite variables, they are calculated based on the coefficients of their respective variables that measure them. Except government and institution factor, the three other factors can strongly impact the Haitian banking stability. But the banking system factor, measured by the bank lending-deposit interest rate spread, can negatively influence banking stability with a coefficient of -0.139 . Each of these three factors is statistically significant at the $1 \%$ level, with respective $\mathrm{p}$-value less than 0.05 . The overall model is statistically significant. A variation in banking stability can be explained by the model at $90 \%$.

Previous studies, such as Shayegani \& Arani (2012), show the impacts of the macroeconomic factor on banking stability. Good macroeconomic conditions 
Table 8. OLS regression analysis of each factor on banking stability.

\begin{tabular}{ccccc}
\hline Vriable & Coefficient & Std. Error & $\mathrm{t}$ value & $\operatorname{Pr}(>|\mathrm{t}|)$ \\
\hline Intercept & -1.865 & 1.348 & -1.384 & 0.17 \\
Macroeconomic factor & 0.595 & 0.053 & 11.167 & $<2 \mathrm{e}-16^{* * *}$ \\
Banking system factor & -0.139 & 0.018 & -7.774 & $1.83 \mathrm{e}-11^{* * *}$ \\
Governance and Institutions factor & -0.102 & 0.088 & -1.159 & 0.25 \\
Economic Freedom factor & 0.452 & 0.452 & 7.701 & $2.56 \mathrm{e}-11^{* * *}$ \\
\hline $\mathbf{R}$ & $\mathbf{R}^{2}$ & $\mathrm{p}$-value & \\
\hline 0.901 & 0.896 & $<2.2 \mathrm{e}-16$ & & \\
\hline
\end{tabular}

Source: Author's own calculation from R Software.

will affect positively bank performance and therefore contribute to maintain the banking stability. The absence of sound macroeconomic policies and effective monetary policy prevent from reaching and maintaining low and stable prices. As a consequence, the bank lending-deposit interest rate spread, also called the financial intermediation spread increases, implying banking instability. Overall, higher freedom of economic activities that banks can undertake will enhance banking stability. With less regulations, banks can even be involved in non- traditional activities that help them to take advantages of economies of scale and make profits. In addition, higher freedom in investment contributes to more businesses and job creation, which will positively affect banks performance. Investors and entrepreneurs that believe the protection of their property is guaranteed will be more likely to undertake economic activities which will increase the banking system stability.

When it comes to the results of the OLS regression analysis of all independent variables on banking stability (Table 9), only the political stability index is not statistically significant. The overall model is strongly statistically significant with a p-value $<2.2 \mathrm{e}-16$, less than 0.05 . The variation observed in banking stability can be explained by the model at $92 \%$.

\subsubsection{OLS Regression Diagnostics: Multicolinearity}

Multicolinearity refers to a situation in which two or more explanatory variables in a multiple regression model are associated with each other and likewise correlated with the dependent variable. Perfect multicolinearity means that the correlation between two independent variables is equal to 1 or -1 . Typically, the issue of multicolinearity arises when an approximate linear relationship among two or more variables explanatory variables. Multicolinearity inflates unnecessarily the standard errors of the coefficients. Multicolinearity makes therefore some variables statistically insignificant when they should be significant. Conversely, without multicolinearity, i.e. with lower standard errors, those independent variables might be statistically significant. The variance inflation factor (VIF) is commonly used to estimate multicolinearity. This measures how much the variance of an estimated regression coefficient increases when independent 
variables are correlated (Akinwande, Dikko \&, Samson, 2015). A rule of thumb for interpreting the VIF is as follows:

- $1=$ not correlated.

- Between 1 and $5=$ moderately correlated.

- Greater than $5=$ highly correlated.

Figure 1 shows the VIFs calculated for all of the independent variables. For each variable, except the bank lending-deposit interest rate spread, the VIF is less than 5, indicating that they are moderately correlated. But a value of 7.1 is not a concern, because for some researchers, a VIF is really considered to be problematic when its value is greater than 10 (Hair Jr. et al., 1995; Shrestha, 2020). Therefore, we can assume that the results of the models are reliable and the significant variables can be known as predictors of the Haitian banking stability.

Table 9. OLS regression analysis of all independent variables on banking stability.

\begin{tabular}{|c|c|c|c|c|}
\hline Variable & Coefficient & Std. Error & t value & $\operatorname{Pr}(>|t|)$ \\
\hline Intercept & -4.340 & 1.451 & -2.991 & $0.00369^{* *}$ \\
\hline Gross Product Domestic Growth (GDP) & 0.179 & 0.039 & 4.558 & $1.83 \mathrm{e}-05^{\star * *}$ \\
\hline Exchange rate (ER) & 0.093 & 0.008 & 11.626 & $<2 \mathrm{e}-16^{\star * *}$ \\
\hline Political stability index (PS) & -0.095 & 0.425 & -0.224 & 0.82307 \\
\hline Regulatory quality index (RQ) & 1.969 & 0.696 & 2.828 & $0.00591^{* *}$ \\
\hline $\begin{array}{l}\text { Bank lending-deposit interest } \\
\text { rate spread (BLIS) }\end{array}$ & -0.124 & 0.029 & -4.241 & $5.93 e-05^{\star * *}$ \\
\hline Investment freedom index (IF) & 0.048 & 0.023 & 2.105 & $0.03847^{\star}$ \\
\hline Property rights index (PR) & 1.295 & 0.137 & 9.473 & $1.04 \mathrm{e}-14^{* * *}$ \\
\hline $\mathbf{R}$ & $\mathbf{R}^{2}$ & p-value & & \\
\hline 0.926 & 0.919 & $<2.2 \mathrm{e}-16$ & & \\
\hline
\end{tabular}

Source: Author's own calculation from R Software.

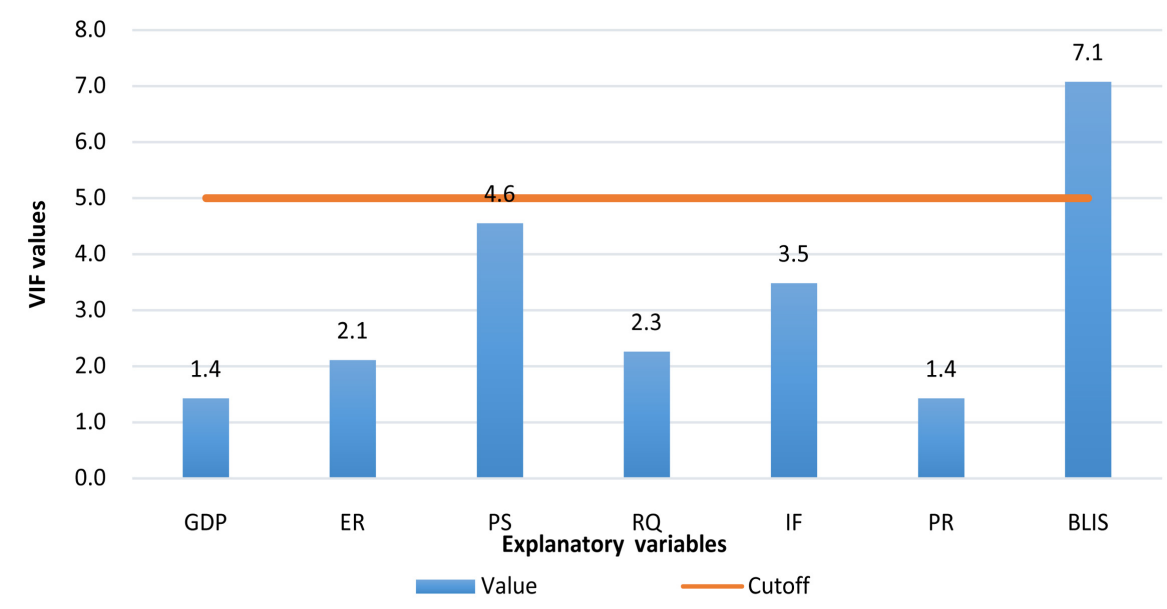

Figure 1. VIF values of all the explanatory variables used in the study. Source: Author's own calculation from R Software. 


\section{Conclusion}

This paper examines the determinants of the banking stability in Haiti, using macroeconomic, government and institutions, banking system, and economic freedom factors measured respectively by GDP growth and exchange rate, political stability index and regulatory quality index, bank lending-deposit interest rate spread, property rights index and investment freedom index. This study uses data over the period of 1996 to 2017. To carry out the analysis, the yearly data have been transformed into quarterly data, giving a sample of 88 observations. Under the OLS regression method, six statistical models have been specified. Banking stability which is the response variable is measured by the Z-score. The results suggest that macroeconomic and economic freedom factors have positive effects on banking stability, while the banking system factor impacts negatively the banking stability in Haiti. An improvement of these two factors will contribute to enhance the banking stability. As well, their deterioration will lead to banking instability. Conversely, government and institutions factor has no significant impact on banking stability. When it comes to assess the impact of each explanatory variable on banking stability, the results indicate that they all have significant effects on the Haitian banking stability. However, we can observe that when all of the independent variables are analyzed in one multiple regression, the political stability index is not statistically significant.

Our results have implications for policymakers. To improve the Haitian banking stability, governments and policymakers should create a macroeconomic environment that could increase the GDP growth and enhance sectors that are oriented towards the exportations, in order to increase the export competiveness. This can be achieved by addressing issues such as lack of productivity, too high interest rates on public loans, too high public deficits or poorly controlled inflation. This will support the fact that banking stability is positively and strongly correlated with the depreciation of the exchange rate. A deterioration of the local currency which is not accompanied by an increase of the national production might yield adverse effects on the economy and consequently on banking stability. This situation can lead to inflation and impact negatively the power purchase of those whose salaries are in Haitian Gourde. Moreover, in order to control banking instability, effective monetary and real interest rates policies should be adopted, implying a reduction of the financial intermediation spread. Money policy refers to what the Central Bank does to influence the amount of money and credit in the Haitian economy. What happens to money and credit affects the interest rates (credit costs) and the performance of the economy. The goals of monetary policy are to promote maximum employment, stable prices and moderate long-term interest rates. By implementing effective monetary policy, BRH can maintain stable prices, thereby supporting conditions for long-term economic growth and employment. With regards to economic freedom, governments and policymakers should work to reinforce the existing laws by removing restrictions on investment and adopting or applying measures that 
could help protect property rights in Haiti. This would contribute to the soundness of banking system and its stability.

However, one of the limitations of this study is that the Z-score as a measure of banking stability is based on only accounting data. Besides, maybe with a larger sample or more explanatory variables, results might be different. Nevertheless, this research paper might contribute to any effort from governments and policymakers to strengthen the Haitian banking sector. Future studies could be interested in investigating the determinants of the Haitian banking stability, using a measure which would be different from the z-score, by considering factors or variables that are not included in this study. The use of another statistical method to run regressions might also be an innovative contribution. For instance, investigating if the relationship between banking stability and its determinants is a long run one or not.

\section{Conflicts of Interest}

The author declares no conflicts of interest regarding the publication of this paper.

\section{References}

Achterberg, E., \& Heintz, H. (2012). Basel III Summary. White Paper Series, RiskQuest. https://www.riskquest.com/wp-content/uploads/2016/09/whitepaper_basel_iii.pdf

Akinwande, M. O., Dikko, H. G., \& Samson, A. (2015). Variance Inflation Factor: As a Condition for the Inclusion of Suppressor Variable(s) in Regression Analysis. Open Journal of Statistics, 5, 754-767. https://doi.org/10.4236/ojs.2015.57075

Ali, M. S. B., Intissar, T., \& Zeitun, R. (2018). Banking Concentration and Financial Stability. New Evidence from Developed and Developing Countries. Eastern Economic Journal, 44, 117-134. https://doi.org/10.1057/eej.2016.8

Allen, F., \& Gale, D. (2004). Competition and Financial Stability. Journal of Money, Credit, and Banking, 36, 453-480.

Alshubiri, F. N. (2017). The Impact of Financial Stability Indexes on Broad Money Growth: Empirical Study in Commercial Banks Listed in Muscat Security Market. International Business Management, 11, 407-414.

Arias, J., Maquieira, C., \& Jara, M. (2019). Do Legal and Institutional Environments Matter for Banking System Performance? Economic Research-Ekonomska Istraživanja, 33, 2203-2228. https://doi.org/10.1080/1331677X.2019.1666023

Barth, J. R., Caprio Jr., G., \& Levibe, R. (2006). Rethinking Bank Regulation: Till Angels Govern. New York: Cambridge University Press. https://doi.org/10.1017/CBO9780511753817

Barth, J. R., Caprio Jr., G., \& Levibe, R. (2013). Bank Regulation and Supervision in 180 Countries from 1999 to 2011. http://faculty.haas.berkeley.edu/ross_levine/papers/Bank_Regulation_and_Supervision _Around_the_World_15JAN2013.pdf https://doi.org/10.3386/w18733

Barth, J. R., Caprio Jr., R., \& Levine, R. (2008). Bank Regulations Are Changing: For Better or Worse? Comparative Economic Studies, 50.

https://doi.org/10.1596/1813-9450-4646 
Beck, T., Demirgüç-Kunt, A., \& Levine, R. (2006). Bank Concentration, Competition, and Crises: First Results. Journal of Banking \& Finance, 30, 1581-1603.

https://doi.org/10.1016/j.jbankfin.2005.05.010

Bhattacharya, S., Plank, M., Strobl, G., \& Zechner, J. (2002). Bank Capital Regulation with Random Audits. Journal of Economic Dynamics and Control, 26, 1301-1321. https://doi.org/10.1016/S0165-1889(01)00045-8

Boyd, J. H., \& De Nicoló, G. (2005). The Theory of Bank Risk-Taking and Competition Revisited. The Journal of Finance, 60, 1329-1343. https://doi.org/10.1111/j.1540-6261.2005.00763.x

Boyd, J. H., \& Graham, S. L. (1986). Risk, Regulation, and Bank Holding Company Expansion into Nonbanking. Quarterly Review, 10, No. 2. https://doi.org/10.21034/qr.1021

Boyd, J. H., Graham, S. L., \& Hewitt, R. S. (1993). Bank Holding Company Mergers with Nonbank Financial Firms: Effects on the Risk of Failure. Journal of Banking \& Finance, 17, 43-63. https://doi.org/10.1016/0378-4266(93)90079-S

BRH (2020). Rapports Statistiques, Supervision Banques. https://www.brh.ht/

Daly, S., \& Frikha, M. (2016). Banks and Economic Growth in Developing Countries: What about Islamic Banks? Cogent Economics \& Finance, 4, Article: 1168728. https://doi.org/10.1080/23322039.2016.1168728

Delis, M., \& Staikouras, P. K. (2011). Supervisory Effectiveness and Bank Risk. Review of Finance, 15, 511-543. https://doi.org/10.1093/rof/rfq035

Diaconu, I.-R., \& Oanea, D.-C. (2015). Determinants of Bank's Stability. Evidence from CreditCoop. Emerging Markets Queries in Finance and Business. Procedia Economics and Finance, 32, 488-495. https://doi.org/10.1016/S2212-5671(15)01422-7

ECVMAS (2012). Enquête sur les Conditions de Vie des Ménages après Séisme 2012. Institut Haïtien de Statistique et Informatique (IHSI), Port-au-Prince, Haïti.

Financial Crisis Inquiry Commission (2011). The Financial Crisis Inquiry Report, Authorized Edition: Final Report of the National Commission on the Causes of the Financial and Economic Crisis in the United States. Washington DC: US Government Printing Office.

Hair Jr., J. F., Anderson, R. E., Tatham, R. L., \& Black, W. C. (1995). Multivariate Data Analysis (3rd ed.). New York: Macmillan.

Hannan, T. H., \& Hanweck, G. A. (1988). Bank Insolvency Risk and the Market for Large Certificates of Deposit. Journal of Money, Credit and Banking, 20, 203-211. https://doi.org/10.2307/1992111

Houben, A., Kakes, J., \& Schinasi, G. (2004). Toward a Framework for Safeguarding Financial Stability. IMF Working Paper, Washington, District of Columbia: International Capital Markets Department.

Karim, N. A., Al-Habshi, S. M. S. J., \& Abduh, M. (2015). Macroeconomics Indicators and Bank Stability: A Case of Banking in Indonesia. Buletin Ekonomi Moneter dan Perbankan, 18, 431-448. https://doi.org/10.21098/bemp.v18i4.609

Kozarić, K., \& Dželihodžić, E. Ž. (2020). Effects of Macroeconomic Environment on Non-Performing Loans and Financial Stability: Case of Bosnia and Herzegovina. Journal of Central Banking Theory and Practice, 9, 6-17. https://doi.org/10.2478/jcbtp-2020-0011

Li, X., Tripe, D., \& Malone, C. (2017). Measuring Bank Risk: An Exploration of Z-Score. https://ssrn.com/abstract $=2823946$ https://doi.org/10.2139/ssrn.2823946 
Mishkin, F. S. (1999). Financial Consolidation: Dangers and Opportunities. Journal of Banking \& Finance, 23, 675-691. https://doi.org/10.3386/w6655

Motelle, S., \& Biekpe, N. (2014). Financial Integration and Stability in the Southern African Development Community. Journal of Economics and Business, 79, 100-117. https://doi.org/10.1016/j.jeconbus.2015.01.002

Mutarindwa, S., Schäfer, D., \& Stephan, A. (2018). The Impact of Institutions on Bank Governance and Stability: Evidence from African Countries. DIW Berlin Discussion Paper No. 1739, Berlin. https://doi.org/10.2139/ssrn.3194396

Ozili, P. K. (2018). Banking Stability Determinants in Africa. International Journal of Managerial Finance, 14, 462-483. https://doi.org/10.1108/IJMF-01-2018-0007

Roy, A. D. (1952). Safety First and the Holding of Assets. Econometrica, 20, 431-449. https://doi.org/10.2307/1907413

Sáez, L., \& Shi, X. (2004). Liquidity Pools, Risk Sharing, and Financial Contagion. Journal of Financial Services Research, 25, 5-23. https://doi.org/10.1023/B:FINA.0000008662.59653.33

Shayegani, B., \& Arani, M. A. (2012). A Study on the Instability of Banking Sector in Iran Economy. Australian Journal of Basic and Applied Sciences, 6, 213-221.

Shrestha, N. (2020). Detecting Multicollinearity in Regression Analysis. American Journal of Applied Mathematics and Statistics, 8, 39-42. https://doi.org/10.12691/ajams-8-2-1

Tan, Y., \& Anchor, J. (2016). Stability and Profitability in the Chinese Banking Industry: Evidence from an Auto-Regressive-Distributed Linear Specification. Investment Management and Financial Innovations, 13, 120-129. https://doi.org/10.21511/imfi.13(4).2016.10

Tan, Y., \& Floros, C. (2013). Risk, Capital and Efficiency in Chinese Banking. Journal of International Financial Markets, Institutions and Money, 26, 378-393. https://doi.org/10.1016/j.intfin.2013.07.009

TheGlobalEconomy (2020). Business and Economic Data. https://www.theglobaleconomy.com/

Uhde, A., \& Heimeshoff, U. (2009). Consolidation in Banking and Financial Stability in Europe: Empirical Evidence. Journal of Banking \& Finance, 33, 1299-1311. https://doi.org/10.1016/j.jbankfin.2009.01.006 